\title{
A SET OF FLUORESCENT PROBES TO STUDY THE I NFLUENCE OF LOW MOLECULAR WEI GHT CRYOPROTECTANTS ON HUMAN ERYTHROCYTE MEMBRANES
}

\author{
Y. Korniyenko*, Y. Posokhov ${ }^{\dagger}$
}

\begin{abstract}
A set of fluorescent probes, which consists of 2-(2'-OH-phenyl)-5-phenyl-1,3-oxazole, 2-(2'-OH-phenyl)-5(4'-phenyl-phenyl)-1,3-oxazole and 2-(2'-OH-phenyl)-9,10-phenantr-1,3-oxazole, has been suggested to study the influence of low molecular weight cryoprotectants, such as glycerol, dimethylsulfoxide and 1,2-propanediol, on human erythrocyte membranes. Using a set of fluorophores with different locations in lipid bilayer enabled to show that under the action of the cryoprotectants the increase in the membrane hydration occurs in polar regions of the erythrocyte membrane, while no changes in hydration have been observed in the most hydrophobic regions of the erythrocyte lipid bilayer. The minimal concentration of the cryoprotectant, which causes the perturbation of the erythrocyte membrane, has been estimated to be 0.5 , 1.5 and $5.0 \%$ vol. for glycerol, dimethylsulfoxide, and 1,2-propanediol, correspondingly. The suggested set of fluorescent probes can be used to monitor the changes of physico-chemical properties in different regions of erythrocyte lipid bilayer under the action of cryoprotectants and to determine optimal concentrations of cryoprotectants for low-temperature storage of the cells.
\end{abstract}

Key words: fluorescent probe, human erythrocyte membrane, cryoprotectants, dimethylsulfoxide, glycerol, 1,2-propanediol.

\section{Introduction}

Low molecular weight cryoprotectants, such as dimethylsulfoxide, glycerol and 1,2-propanediol, are widely used in biology, medicine and biotechnology for the long-term storage of the human and animal cells at low temperatures [1]. Unfortunately, at high concentrations cryoprotectants can influence membrane integrity of cell membranes even before freezing [2]: such negative influence vary between different types of cells. Thus, in order to make optimal choice of cryoprotectant concentration for the low-temperature storage of the definite type of cells one should study the influence of the cryoprotectant on the structural integrity of the cell membrane before freezing.

Due to high sensitivity and informativity, fluorescent methods are a valuable tool to study structural modifications of biomembranes [3]. In literature one can find a few examples of the fluorescent probe usage to study the influence of low molecular weight cryoprotectants, such as dimethylsulfoxide, glycerol and 1,2-propanediol, on cell membrane structural integrity: e.g., Giraud et al. [4] used fluorescence anisotropy measurements of diphenylhexatriene (DPH) to study action of glycerol on human spermatozoa membrane; Dyubko et al. [5] used 3-hydroxy-4'-(N,N-dimethylamino)flavone (FME) to study an influence of low molecular weight cryoprotectants on rat liver microsome membranes. In each of the above cases only one fluorescent probe was used to study the changes in lipid membranes: such experimental scheme did not allow to monitor the changes of physico-chemical properties in different regions of lipid bilayer.

This article describes the possibility to use a set of fluorescent probes, which consists of a few ortho-hydroxy derivatives of 2,5-diaryl-1,3-oxazole, in order to monitor the changes in different areas of human erythrocyte membrane (i.e. both in polar and apolar regions of lipid bilayer) under the influence of cryoprotectants (dimethylsulfoxide, glycerol and 1,2-propanediol).

\section{Materials and methods}

Synthesis and purification of 2-(2'-OH-phenyl)-5-phenyl-1,3-oxazole, 2-(2'-OH-phenyl)-5-(4'phenyl-phenyl)-1,3-oxazole and 2-(2'-OH-phenyl)-9,10-phenantr-1,3-oxazole were described elsewhere [6,7]. Dimethylsulfoxide, glycerol and 1,2-propanediol were from "Sigma-Aldrich Russia".

Red blood cells (erythrocytes) were obtained from human blood by centrifugation at $3000 \mathrm{rpm}$ for 3 minutes (the blood was centrifuged three times). The obtained erythrocytes were resuspended in

\footnotetext{
${ }^{*}$ Department of Physiology, V.N. Karazin Kharkov National University, Svobody sq. 4, 61077 Kharkov, Ukraine ${ }^{\dagger}$ Institute for Chemistry, V.N. Karazin Kharkov National University, Svobody sq. 4, 61077 Kharkov, Ukraine
} 
physiological solution $(0.15 \mathrm{M})$ at room temperature $\left(20^{\circ} \mathrm{C}\right)$. After addition of cryoprotectants the suspensions of erythrocytes were equilibrated at $20^{\circ} \mathrm{C}$ for 40 minutes.

The suspension of erythrocytes, used for the fluorescence measurements, had absorption 0.02 at $545 \mathrm{~nm}$. For all the fluorescence measurements, the cells were fluorescently labeled using the same procedure. Since the solubility of the probes is limited in water, the $0.2 \mathrm{mM}$ stock solution of the probes in acetonitrile was used. An aliquot of $0.2 \mathrm{mM}$ stock solution of the probe in acetonitrile was added to physiological solution with erythrocytes (i.e. acetonitrile final concentration was $\leq 0.5 \%$ ) to achieve final probe concentration of $1 \mu \mathrm{M}$. The cell suspension was then incubated with the probes in the dark at room temperature for 1 hour before fluorescence measurements.

Fluorescence spectra were recorded on a Hitachi F850 steady-state fluorescence spectrometer at room temperature. The slits on excitation and emission monochromators were $5 \mathrm{~nm}$. The measurements were made in a $10 \mathrm{~mm} \times 10 \mathrm{~mm}$ cuvette. An excitation wavelength was $330 \mathrm{~nm}$. Emission was recorded in the range of $340-620 \mathrm{~nm}$, with an increment of $1 \mathrm{~nm}$. Data were collected with a $1 \mathrm{~s}$ interval.

\section{Results and discussion}

Ortho-hydroxy derivatives of 2,5-diaryl-1,3-oxazole have been chosen for the study because of their high sensitivity to the parameters of the environment, such as polarity, viscosity and hydrogenbonding ability [6-12]. In the excited state the ortho-hydroxy derivatives of 2,5-diaryl-1,3-oxazole are capable of isomerization via the excited state proton transfer (ESIPT) reaction (Fig. 1): hydroxyl group in the ortho-position of the lateral benzene ring acts as protonodonor and the nitrogen atom of oxazole ring acts as proton acceptor [6-12]. The result of the ESIPT reaction is the formation of phototautomeric form $\left(\mathrm{T}^{*}\right)$, fluorescent in significantly longer wavelengths in comparison with the initial form $\left(\mathrm{N}^{*}\right)[6-12]$.

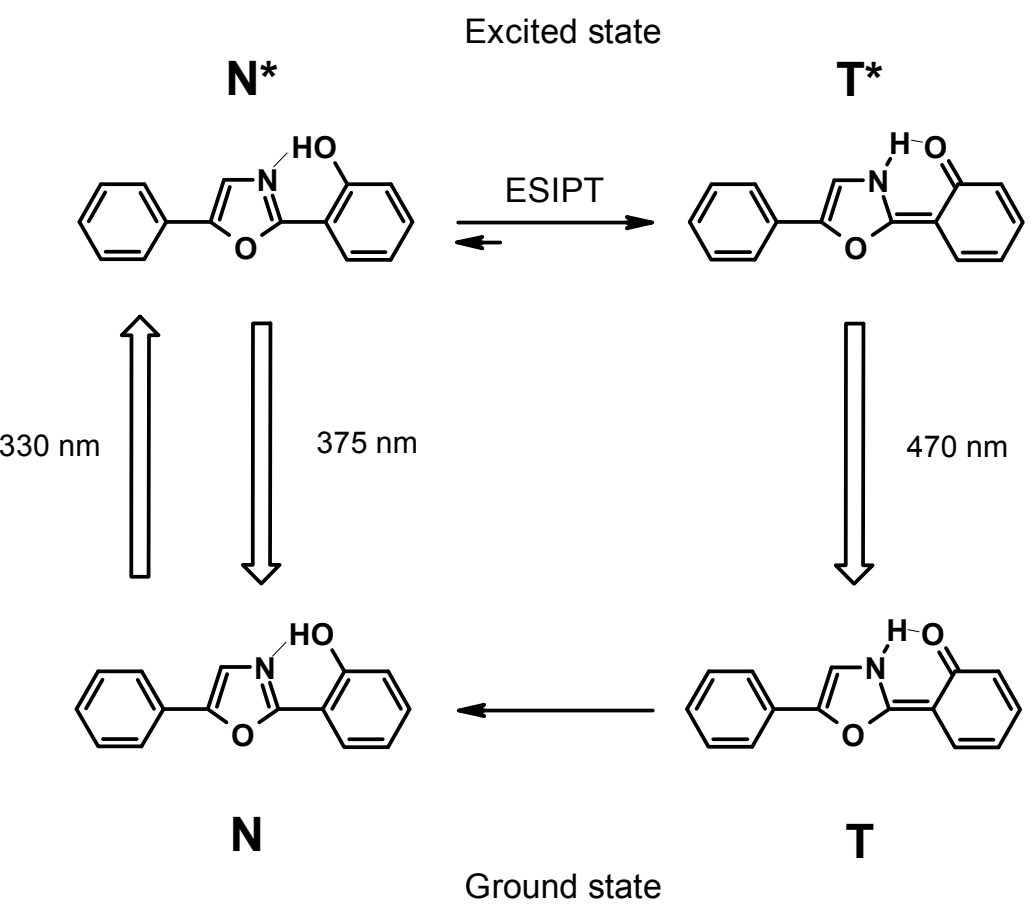

Figure 1. Scheme of excited state proton transfer (ESIPT) reaction in 2-(2'-OH-phenyl)-5-phenyl-1,3oxazole. Upwards arrow shows the electronic excitation and downwards arrow represents the light emission (fluorescence). Corresponding maxima of absorption and fluorescence are measured in nanometers.

The position and intensity of the fluorescence of each form depend not only on the chemical structure, but also on the parameters of the molecule microenvironment [6-12]. 
The presence of two-band fluorescence allows to perform ratiometric measurement, i.e. to use the ratio of phototautomeric form and the initial form fluorescence intensities $\left(I_{T^{*}} / I_{\mathrm{N}^{*}}\right)$ as a parameter for evaluation of the physical and chemical properties of the microenvironment. The use of ratiometric fluorescent probes allows to exclude the measurement error associated with the deviation of the fluorescent probe concentration (e.g., uneven distribution of the fluorescent probe in various membranes) and the measurement error associated with a deviation of fluorescence equipment settings (deviation of the intensity of the exciting source, a change in focus, changes in the sensitivity of the photodetector, etc.) [13].

A few ortho-hydroxy derivatives of 2,5-diaryl-1,3-oxazole that differ in their lipophilicity [8-11] were selected for the present study (Fig. 2): 2-(2'-OH-phenyl)-5-phenyl-1,3-oxazole (probe 1), 2-(2'-OH-phenyl)-5-(4'-phenyl-phenyl)-phenyl-1,3-oxazole (probe 2) and 2-(2'-OH-phenyl)-9,10phenantr-1,3-oxazole (probe 3). It is expected that the regions of location of selected probes in the membrane are different and correspond to the lipophilicity of the probes (Fig. 2) [8-11]. Expected location and orientation of probes $\mathbf{1}, \mathbf{2}$ and $\mathbf{3}$ in lipid membranes is based on their fluorescence properties in lipid membranes [8-11] and on the basis of their structural similarity with fluorescent probes with known location in lipid membranes [3]. The location of the probes in lipid membranes: probe $\mathbf{1}$ - in the area of glycerol residues of phospholipids and in the area of carbonyl groups of phospholipids; probe 2 - in the area of carbonyl groups of phospholipids and in the area of methylene groups of phospholipids near the polar region of the bilayer; probe $\mathbf{3}$ - in the area of methylene groups of phospholipids near the center of the bilayer and in the center of the bilayer (Fig. 2).

The fluorescence spectra of the probes 1, 2 and $\mathbf{3}$ in human erythrocyte membranes before and after the action of dimethylsulfoxide are shown on Fig. 3.
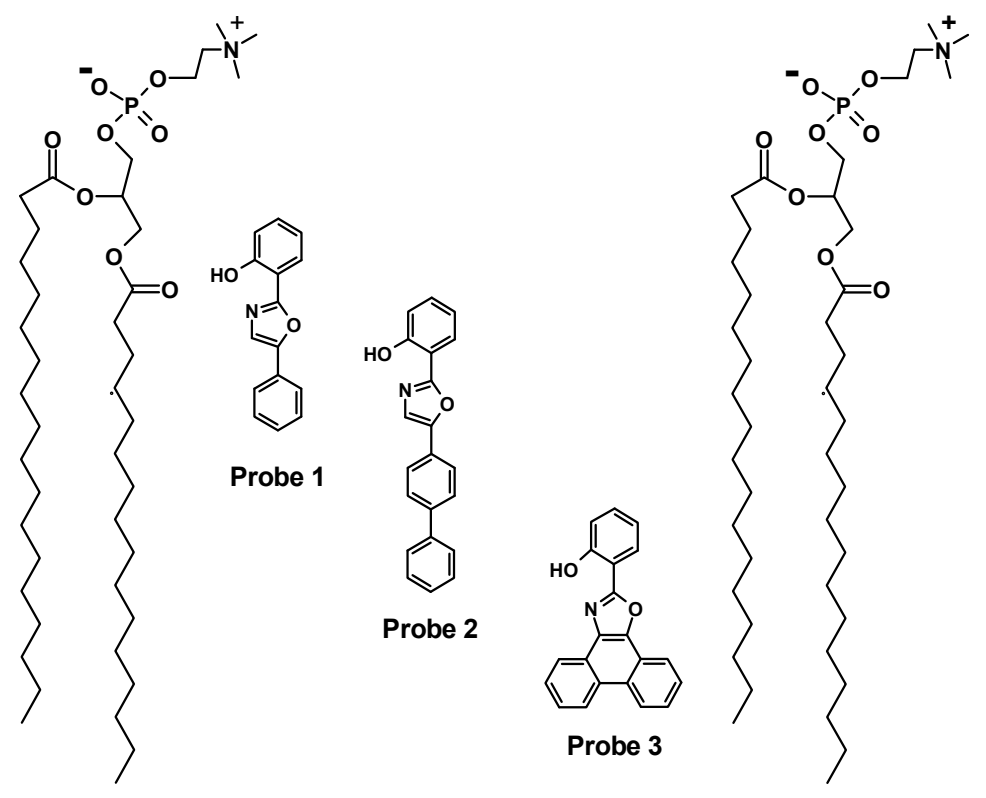

Figure 2. Expected location and orientation of fluorescent probes 1, 2 and 3 based on their fluorescence properties in lipid membranes [8-11] and on the basis of their structural similarity with fluorescent probes with known localization in lipid membranes [3]. Two molecules of phosphatidylcholine from the outer monolayer are shown to denote the localization of the probes.

Two fluorescence bands are observed in each fluorescence spectrum presented in Fig 3: shortwavelength band is the fluorescence of the initial form ( $\mathrm{N}^{*}$, see Fig. 1) and long-wavelength band is the fluorescence of the phototautomer form ( $\mathrm{T}^{*}$, see Fig. 1).

According to Fig. 3, the action of dimethylsulfoxide on erythrocyte membranes resulted in the increase of the fluorescence intensity of the normal form $\left(\mathrm{I}_{\mathrm{N}^{*}}\right)$, in the decrease of the ratio $\mathrm{I}_{\mathrm{T}^{*}} / \mathrm{I}_{\mathrm{N}^{*}}$ and in hypsochromic (i.e. short-wavelength) shift of the phototautomer fluorescence of the probes $\mathbf{1}$ and $\mathbf{2}$, at the same time, no noticeable changes were observed for the probe 3 . Similar results were observed in 
case of action of high concentrations of glycerol or 1,2-propanediol on the erythrocyte membranes (not shown).

The observed hypsochromic shift of phototautomer fluorecscence bond and decrease of the ratio $\mathrm{I}_{\mathrm{T}^{*}} / \mathrm{I}_{\mathrm{N}^{*}}$ for probes $\mathbf{1}$ and $\mathbf{2}$ in erythrocyte membranes after the action of the cryoprotectants are indicative of an increase in polarity and hydrogen-bonding ability in the lipid membrane regions, where probes 1 and 2 are located. Such changes point to the increase in hydration of the lipid membrane [14-16] in the regions, where probes 1 and $\mathbf{2}$ are located: in the area of glycerol residues of phospholipids, in the area of carbonyl groups of phospholipids and in the area of methylene groups of phospholipids near the polar region of the bilayer. The increase in hydration may be caused by the perturbation of the membrane lipid packing [15]. Moreover, taking into account that glycerol and 1,2-propanediol are cryoprotectants penetrating into membrane [5, 17-20] (i.e. so-called "membranepermeable cryoprotectants" [20]), one can suggest that the abovementioned increase in the hydration of the erythrocyte membrane may be due to the accumulation of hydrated cryoprotectant molecules in the membrane [5].

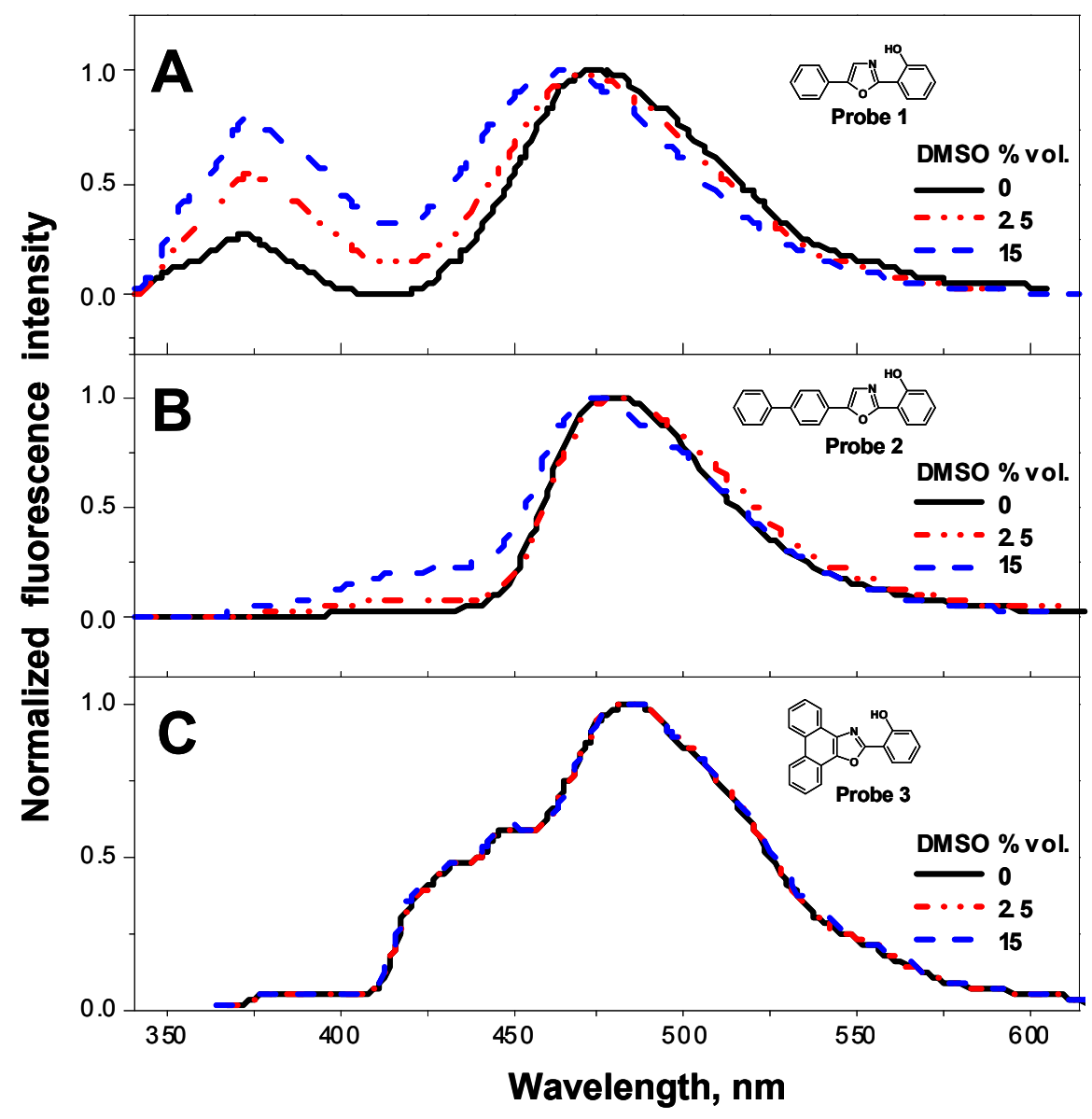

Figure 3. Normalized fluorescence spectra of probes $\mathbf{1}$ (A), 2 (B) and $\mathbf{3}$ (C) in human erythrocyte membranes in the presence of different concentrations (\% vol.) of dimethylsulfoxide (DMSO): (a) 0 (solid line), (b) 0.5 (dash-dot-dot line), (b) 15 (dashed line).

The influence of cryoprotectant concentration growth on the ratio of phototautomeric form and the initial form fluorescence intensities $\left(\mathrm{I}_{\mathrm{T}^{*}} / \mathrm{I}_{\mathrm{N}^{*}}\right)$ of probes $\mathbf{1}, \mathbf{2}$ and $\mathbf{3}$ is shown on Fig. 4.

It is found that initial concentration of cryoprotectant that causes perturbation of human erythrocyte membrane is $0.5,1.5$ and $5.0 \%$ vol. for glycerol, dimethylsulfoxide and 1,2-propanediol, correspondingly. 
Thus, the ortho-hydroxy derivatives of 2,5-diaryl-1,3-oxazole can be used to determine optimal concentrations of cryoprotectants for low-temperature storage of the cells.

According to Figs. 3 and 4, there are no changes in the fluorescence spectra (and, thus, in the ratio $\mathrm{I}_{\mathrm{T}^{*}} / \mathrm{I}_{\mathrm{N}^{*}}$ ) of probe 3 in human erythrocyte membranes after the action of the cryoprotectants. This result shows that the used cryoprotectants do not affect the regions, where probe $\mathbf{3}$ is located: i.e. the area of methylene groups of phospholipids near the center of the bilayer and the center of the bilayer.

Summarizing the results for probes 1-3, one can conclude that the suggested set of fluorescent probes enables to monitor the changes of physico-chemical properties in different regions of erythrocyte lipid bilayer under the influence of the cryoprotectants.

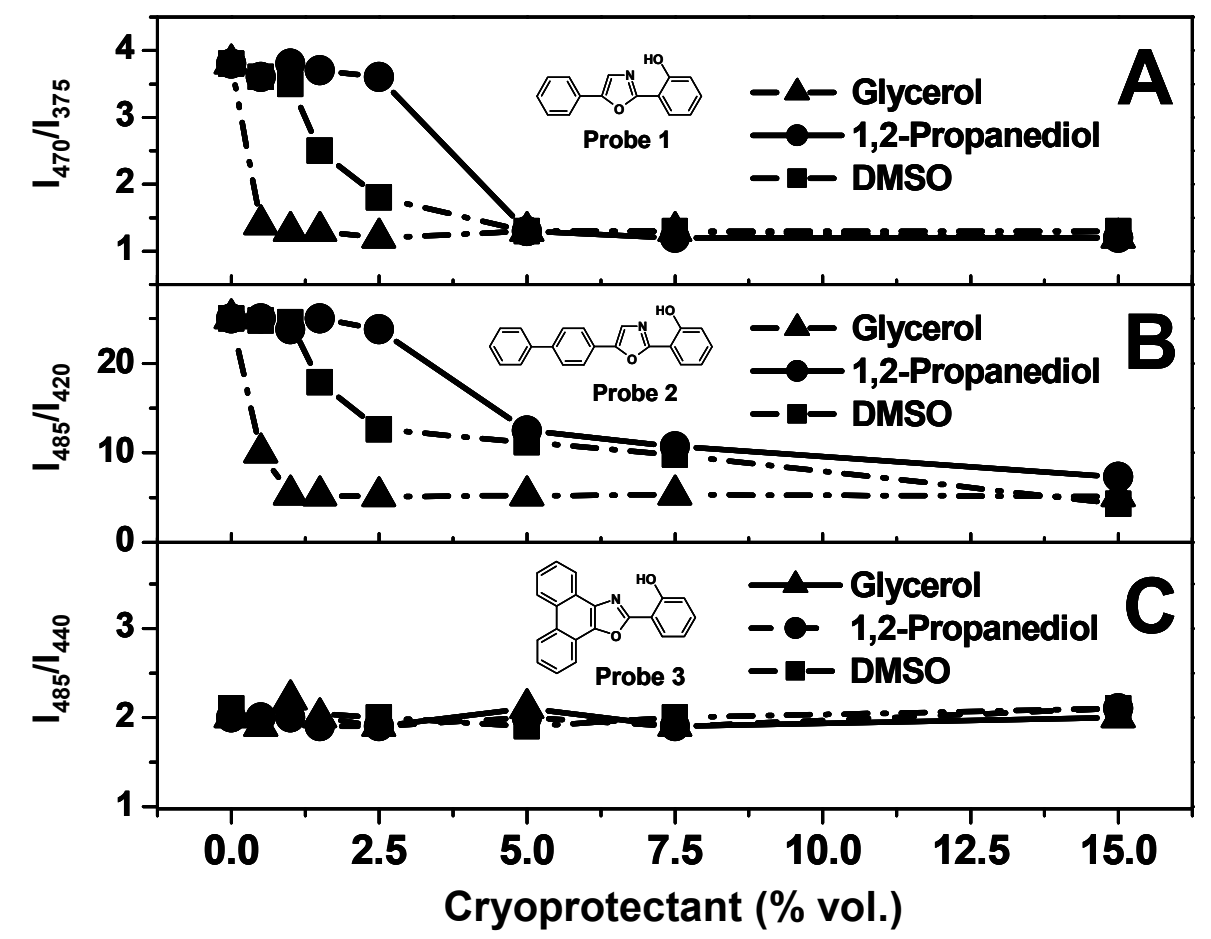

Figure 4. The influence of cryoprotectants (dimethylsulfoxide (squares), glycerol (triangles) and 1,2-propanediol (circles)) on the fluorescence intensity ratio $\mathrm{I}_{\mathrm{T}^{*}} / \mathrm{I}_{\mathrm{N}^{*}}$ of probes $\mathbf{1}(\mathrm{A}), \mathbf{2}(\mathrm{B})$ and $\mathbf{3}(\mathrm{C})$ in human erythrocyte membranes.

\section{Conclusions}

A set of fluorescent probes, which consists of 2-(2'-OH-phenyl)-5-phenyl-1,3-oxazole, 2-(2'-OHphenyl)-5-(4'-phenyl-phenyl)-1,3-oxazole and 2-(2'-OH-phenyl)-9,10-phenantr-1,3-oxazole, has been suggested to study the influence of low molecular weight cryoprotectants, such as glycerol, dimethylsulfoxide and 1,2-propanediol, on human erythrocyte membranes. Using a set of fluorophores with different locations in lipid bilayer enabled to show that under the action of the cryoprotectants the increase in the membrane hydration occurs in polar regions of the erythrocyte membrane, while no changes in hydration have been observed in the most hydrophobic regions of the erythrocyte lipid bilayer. The minimal concentration of the cryoprotectant, which causes the perturbation of the erythrocyte membrane, has been estimated to be $0.5,1.5$ and $5.0 \%$ vol. for glycerol, dimethylsulfoxide and 1,2-propanediol, correspondingly. The suggested set of fluorescent probes can be used to monitor the changes of physico-chemical properties in different regions of erythrocyte lipid bilayer under the action of cryoprotectants and to determine optimal concentrations of cryoprotectants for low-temperature storage of the cells. 


\section{Acknowledgment}

The authors are grateful to Prof. A.O. Doroshenko for supplying us with the derivatives of 2,5-diaryl-1,3-oxazole.

\section{References}

1. B. J. Fuller, E. E. Benson, N. Lane, Life in the Frozen State, New York: CRC Press, 2004.

2. T. Arakawa, J. F. Carpenter, Y. A. Kita, J. H. Crowe, "Basis for toxicity of certain cryoprotectants: a hypothesis," Cryobiology, vol. 27, iss. 4, pp. 401-415, 1990.

3. G. E. Dobretsov, Fluorescence Probes in Cell, Membrane and Lipoprotein Investigations, Moscow: Nauka, 1989.

4. M. N. Girtaud, C. Motta, D. Boucher, G. Grizard, "Membrane fluidity predicts the outcome of cryopreservation of human spermatozoa," Human Reproduction, vol. 15, no. 10, pp. 2160-2164, 2000.

5. T. S. Dyubko, E. V. Onishchenko, V. G. Pivovarenko, "Influence of freezing and low molecular weight cryoprotectants on microsomal membrane structure: a study by multiparametric fluorescent probe,” J. Fluorescence, vol. 16, pp. 817-823, 2006.

6. A. O. Doroshenko, E. A. Posokhov, V. M. Shershukov, V. G. Mitina, O. A. Ponomarev, "Intramolecular proton-transfer reaction in an excited state in a series of ortho-hydroxy derivatives of 2,5-diaryloxazole," High Energy Chemistry, vol. 31, no. 6, pp. 428-435, 1997.

7. A. O. Doroshenko, E. A. Posokhov, A. A. Verezubova, L. M. Ptyagina, V. T. Skripkina, V. M. Shershukov, "Radiationless deactivation of the excited phototautomer form and molecular structure of ESIPT-compounds," Photochem. Photobiol. Sci., vol. 1, pp. 92-99, 2002.

8. Y. O. Posokhov, "A set of fluorescent probes for determination of physical-chemical properties of lipid membranes," Patent 68871 UA - Published. 10.04.2012, Bull, no. 7 (in Ukrainian).

9. E. A. Posokhov, N. A. Abmanova, T. P. Boyko, A. O. Doroshenko, "Ortho-hydroxy derivatives of 2,5-diphenyl-1,3-oxazole and 2,5-diphenyl-1,3,4-oxadiazole as fluorescent probes for medical and biological research," Kharkov University Bulletin (Chemical Series), no. 454, iss. 4(27), pp. 188-190, 1999 (in Russian).

10. Y. O. Posokhov, "Ortho-hydroxy derivatives of 2,5-diphenyl-1,3-oxazole and 2,5-diphenyl1,3,4-oxadiazole as fluorescent probes for toxicological study of the cells of olfactory analyzer of rats," Kharkov University Bulletin (Chemical Series), no. 976, iss. 20(43), pp. 92-99, 2011 (in Russian).

11. E. A. Posokhov, T. P. Boyko, D. A. Bevziuk, "Ortho-hydroxy derivatives of 2,5-diphenyl-1,3oxazole and 2,5-diphenyl-1,3,4-oxadiazole as fluorescent probes for toxicological investigations of model membranes," Kharkov University Bulletin (Chemical Series), no. 532, iss. 7(30), pp. 192-194, 2001 (in Russian).

12. A. O. Doroshenko, E. A. Posokhov, "Proton phototransfer in a series of ortho-hydroxy derivatives of 2,5-diaryl-1,3-oxazole and 2,5-diaryl-1,3,4-oxadiazole in polystyrene films," Theoretical and Experimental Chemistry, vol. 35, iss. 6, pp. 334-337, 1999.

13. H. M. Shapiro, Flow Cytometry, New York: Science, 1995.

14. C. Ho, C. D. Stubbs, "Hydration at the membrane protein-lipid interface," Biophysical Journal, vol. 63, pp. 897-902, 1992.

15. C. Ho, S. J. Slater, C. D. Stubbs, "Hydration and order in lipid bilayers," Biochemistry, vol. 34, pp. 6188-6195, 1995.

16. E. A. Disalvo, F. Larion, F. Martini, E. Tymczyczyn, M. Frias, "Structural and functional properties of hydration and confined water in membrane interfaces," Biochimica et Biophysica Acta, vol. 1778, pp. 2655-2670, 2008.

17. O. I. Gordiyenko, T. P. Linnik, E. O. Gordiyenko, "Erythrocyte membrane permeability for a series of diols," Bioelectrochemistry, vol. 62, pp. 115-118, 2004.

18. E. V. Davydova, O. I. Gordienko, "Temperature effect on erythrocyte membrane permeability for cryoprotectants with different hydrophobicities," Problems of Cryobiology, vol. 19, no. 3, pp. 261-272, 2009.

19. G. V. Kovalenko, I. F. Kovalenko, T. P. Linnik, "The mechanism of DMSO, glycerol and ethylene glycol transport across rat and rabbit erythrocyte membranes," The Journal of V.N. Karazin Kharkiv National University. Series: Biology, iss. 10, no. 878, pp. 109-116, 2009 (in Russian). 
20. H. Oldenhof, M. Gojowsky, S. Wang, S. Henke, C. Yu, K. Rohn, W. F. Wolkers, H. Sieme, "Osmotic stress and membrane phase changes during freezing of stallion sperm: mode of action of cryoprotective agents," Biology of Reproduction, vol. 88, no. 3, pp. 1-11, January 2013.

Поступила до редакиії 11 січня 2016 р.

Е. А. Посохов. Набор фрлоресцентных зондов для исследования влияния криопротекторов с низкой молекулярной массой на мембраны эритроцитов человека.

Набор фрлуоресцентных зондов, состоящий из 2-(2'-ОН-френил)-5-френил-1,3-оксазола, 2-(2'-ОН-френил)-5(4'-фенил-фенил)-1,3-оксазола и 2-(2'-ОН-френил)-9,10-фенантр-1,3-оксазола, был предложен для исследования влияния криопротекторов с низкой молекулярной массой, таких как глицерин, диметилсульфоксид и 1,2-пропандиол, на мембраны эритроцитов человека. Использование набора флуорофоров, имеющих различную локализацию в липидном бислое, позволило показать, что при воздействии криопротекторов происходит увеличение гидратации полярных областей мембраны эритроцита, в то же время никаких изменений степени гидратации наиболее гидрофобных областей липидного бислоя эритроцита обнаружено не было. Оценена минимальная концентрация криопротектора, при которой происходят изменения в мембране эритроцита: 0,5, 1,5 и 5,0 \% об. для глицерина, диметилсульфоксида и 1,2-пропандиола, соответственно. Предложенный набор флуоресцентных зондов может быть использован для мониторинга изменений физико-химических свойств в различных областях липидного бислоя эритроцита под действием криопротекторов и для оценки оптимальных концентраций криопротекторов для низкотемпературного хранения клеток.

Ключевые слова: флуоресцентные зонды, мембрана еритроцита человека, криопротектор, глицерин, диметилсулфоксид, 1,2-пропандиол.

Є. О. Посохов. Набір фрлуоресцентних зондів для дослідження впливу кріопротекторів з низькою молекулярною масою на мембрани еритроцитів людини.

Набір фрлуоресцентних зондів, який складається з 2-(2'-ОН-френіл)-5-феніл-1,3-оксазолу, 2-(2'-ОН-феніл)5-(4'-френіл-феніл)-1,3-оксазолу і 2-(2'-ОН-феніл)-9,10-фенантр-1,3-оксазолу, було запропоновано для дослідження впливу кріопротекторів з низькою молекулярною масою, таких як гліцерин, диметилсульфоксид і 1,2-пропандіол, на мембрани еритроцитів людини. Використання набору флуорофорів, які різняться локалізацією в ліпідному бішарі, дозволило показати, що під дією кріопротекторів відбувается збільшення гідратації полярних областей мембрани еритроцита, в той же час ніяких змін ступеня гідратації найбільш гідрофобних областей ліпідного бішару еритроцита виявлено не було. Було оцінено мінімальну концентрацію кріопротектору, яка спричиняє зміни у мембрані еритроцита: 0,5, 1,5 і 5,0 \% об. для гліцерину, диметилсульфоксиду і 1,2-пропандіолу, відповідно. Запропонований набір флуоресцентних зондів може бути використаний для моніторингу змін фрізико-хімічних властивостей у різних областях ліпідного бішару еритроцита під дією кріопротекторів і для визначення оптимальних концентрацій кріопротекторів для низькотемпературного зберігання клітин.

Ключові слова: флуоресцентні зонди, мембрана еритроцита людини, кріопротектор, гліцерин, диметилсулфоксид, 1,2-пропандіол.

Kharkov University Bulletin. Chemical Series. Issue 26 (49), 2016 